\title{
Representation of Language in Social Media: A Case Study of the Facebook Users in Desa Larangan
}

\author{
Suparni Bt Carmudi ${ }^{1}$ and Lila Wati Kurnia ${ }^{2}$ \\ \{maniez.efgs@gmail.com¹,purplemoon08@gmail.com²\} \\ ${ }^{1,2}$ Universitas Indonesia, Jakarta, Indonesia
}

\begin{abstract}
Language both used verbally and in writing will represent the identity of the users. That is why the use of language must be adapted to the context. This research is interested in the use of local and mixed languages on social media. By using the concept of representation from Stuart Hall, this study attempts to examine the relation between the use of language on social media and the user's self-representation. This research uses quantitative methods with cultural studies approach to examine how the media facilitates the community in representing their identity. This research departs from the phenomenon of the use of local languages and mixtures which are often found by Facebook users in the village of Larangan-Brebes, thus data is collected through netnography. In addition, the author also collects ethnographic data such as observation and direct interviews which aims to see how language is used in daily life by the participants. The result shows that the use of Facebook in the rural context represents modernity or progress in the Larangan community. On the other hand, the use of local and mixed languages supported by personal topics automatically represents the inability of Facebook users to distinguish between public space and private space. Eventually, this phenomenon illustrates the lack of understanding of their media literacy.
\end{abstract}

Keywords: representation, local dan mixed languages, publik and private space, social media

\section{INTRODUCTION}

Facebook, for its easy accessibility, has become one of the most popular social networking site used by people in Desa Larangan, Kecamatan Larangan, Kabupaten Brebes. The popularity of Facebook as a new instrument in communication and social interaction motivates the poople in the village to widely use it to socialize and interact in a vitural world. In line with the use of Facebook as a social media in general, the people in Desa Larangan use Facebook to communicate and find friends.

Some previous studies that examined Facebook also explained the same thing as the research conducted by [1] the results of his research show that Facebook is widely used because social media is easy to use, the network is wide, and there are group features that make it easy to interact based on similarity, especially when it is related to business. While the 
research from [2]Facebook, for digital native (internet user community) serves as a medium to represent self-identity through status updates and background status on the newsfeed. Other research shows Facebook is used to maintain the self-existence online. The use of Facebook in this way represents an awareness that Facebook is an open social space or public space so that they use the Wall feature and profile to construct self-identity online. [3] explained that the photo profile, image status and other features that represent the account make the owners of the account have a magazine about them to maintain their existence in the virtual world. Different findings were reviewed by [4]in his research, stating that the profile, status and Wall features that can be used to construct the identity of the users can not be accounted for.

The previous research showed that Facebook users have a thorough understanding on the features provided on Facebook when they use it to find friends or to interact virtually. The research also implied that the representation built by Fecebook users is embodied by what they choose to display on their Facebook feed. The vast and huge social networking of Facebook enable its users to gain an experience of connecting and building relationship with people from across the cities and even countries, and indeed people they have never met in person, [5]. By understanding this notion of Facebook as a huge and popular social networking site, the users are considering the language feature as a part of the practices. This resulted in the attempt to modify the use of language to easily adjust and reach the audiences and other Facebook users.

Facebook users in Desa Larangan showed different pattern in utilizing language as a tool to communicate. Facebook's online space is used differently and focused on three things, the use of mixed language to communicate, private message, and private discussion as a part of public display of communication in using Facebook as a social media. These three things narrowed down Facebook's social space as an international platform into a localized social media platform where the interaction between the users especially those in Desa Larangan happened only in the small circle or group of friends. This categorization represents that the social interaction mediated by Facebook is similar to the face-to-face interaction where one person is directly communicating with the other without the help of social media or social networking site. This also implied that there is a sense of negligence from the Facebook users to fully realize and grasp the core of Facebook as a public space. Facebook users of Desa Larangan make use of mixed language which consisted of local language, English, and Bahasa to communicate and send messages privately through the home of Facebook. This showed the lack of insight to distinguish between public and private space and the practice also further represent the identity of the user.

This research will analyze the use of language in social media as a mean to represent modern lifestyle but also at the same time to express locality throughout the practice in the village community. Previous researches will be attached to grasp the differences between Facebooks' public and private spaces. Stuart Hall's theory of representation and identity is used to investigate how the representation and identity are built through the use of language in an online space. Hall [6] argued that representation is an important part in the formation of meaning. To be able to understand the meaning of the object represented, one must have the same language and culture code. Thus the meaning of the object presented can be disseminated and exchanged between groups in a culture.

\section{METHOD}

Applying a textual analysis from the perspective of cultural studies, this article aims to explore and investigate the role of Facebook as a social media in constructing local identity through the use of language from the active users in Desa Larangan. This research employs 
both etnography and netnography to collect the data. "Netnography is etnography adapted to the study of online communities [7]. Netnography is used to understand how social media users in Desa Larangan are actively engaging in the online practice to construct a new local identity by using mixed languages and interacting with people they know. Netnography is applied as a method in collecting the data from a few Facebook accounts selected for the research. Direct observation and interview are done to better understand how Facebook users in Desa Larangan construct meaning-making in interacting with others through Facebook..

\section{RESULT AND DISCUSSION}

The writer chose Facebook as the subject on this research based on the fact that Facebook is the most popular and most used social networking site by the people in Desa Larangan. 5 Facebook accounts were selected as the corpus of study due to the intensity of these accounts using Facebook and practicing the mixed languages. The mixed languages consist of local language Jawa Ngapak, or a local Javanese language used in Larangan, Brebes, Online Language (Internet Slang), and Bahasa. Based on this, the data taken is in a form of texts from the selected accounts' posts. This research will not discuss type of languages or any form language structures and will only focus on the meaning-making of the use of mixed languages to represent the locality and identity of people in Desa Larangan through Facebook.

\subsection{Public and Private Space in Facebook}

Public space is a place for people from various backgrounds gather and exchange information and commodities. Social media is a form of public place. It can be interpreted as a public space due to its nature as an open and wide virtual space with vast and fluid social exchange. It is accessible for everyone and the engagement rate makes it easy for people to use social media like Facebook to have an open and public discussion. For Facebook users in the village [8] argued that the 'friends' or 'follow friends' feature in Facebook enable its users to create a community or a group for people who are located in the same area. These groups and communities functioned as a media to promote the village events and activities. Similar finding is stated by [9] in seeing Facebook as a new media which served purpose as a public space by ICS Fanpage to share information and submit a complaint and suggestion to the local government. The previous research stated that Facebook is a social space that functioned for social purposes. [10]) argued that social media is an open social space which act as a representation of the users who use that social media. This can be seen from the online profile which is uploaded as a part of the identity for people to see. Burkell also added that this public space can function as a private space too by limiting the audience that can see the posts from the users or the owner of the accounts.

By filtering the target audience of the Facebook friends, the user or the owner of the account can choose privacy feature and only let a few selected people to be able to see their private posts. [11] explained that Facebook applies a soft control in relation to the online space which has a very free nature. Ford also suggested that Facebook users to think and write carefully before deciding to post anything to their Facebook without having to limit the audiences. [10] and [11] agreed that the public space in Facebook can be negotiated by setting the privacy feature to be able to filter and limit the audience that can see the posts. This conclusion suggested Facebook users to have a good understanding of literacy skills in using this online space particularly social media wisely. 


\subsection{General Description of Facebook Use}

As a technology that enters the countryside or village area, the presence of Facebook brings new colors in several aspects of life, one of which is to interact socially. According to the 5 selected informants, their motivation to make Facebook was, first to find friends and build friendships, and second to follow the prevailing trends at that time which were all about Facebook. Based on the intensity and reasons for updating Facebook status in a day, from the five existing accounts, the account of @Tri Widia Puspitaningrum and@Tina Takizawa are seen as the most active in updating status on the homepage and profile photo. From the interview with Tri (housewife, 28 years old) it can be concluded that she uses her account mostly for online selling and as an act of self-expression related to her personal life. Within a day she can upload 5-8 times. The more she uploads, the more she accesses her account because she also actively responds to every comment. While Indah (housewife, 36 years), the account owner@Tina Takizawa mostly uses her account to express herself and much of the information uploaded on her account consists of personal information. Within a day she can upload 7-10 times. She once posted 30 times a day. According to her, Facebook is like a husband and a friend, thus if there is anything related to her, whether something fun or disappointing, she will share it to her Facebook page. Judging from the intensity of uploading and the types of uploads; they make Facebook as a part of their daily routine that makes them always want to access it through their smart phone. This finding is in line with [12]which revealed that $65 \%$ of Facebook users in Indonesia most often open Facebook on a bed. Through notification that pops up on their gadget, they will check it then continue to do other things such as checking their friends' online status, searching online product links and looking for other information.

While three other informants@Chacha Mariska Heyhey (health worker, 28 years) @Bunda Alya (elementary school teacher, 35 yrs), and @Triyono Rengganiest (entrepreneur, $35 \mathrm{yrs}$ ) said that Facebook provided a lot of convenience not only in communication and interaction, but also for other purposes for example to facilitate personal self-presentation. In addition, the three informants admitted that before having Facebook account, only their close friends and neighbors knew them so well, but today through Facebook everyone can construct their online identity by posting selfie photos or wise words that describe their personality. It is not weird to use Facebook online space for the purpose as it also revealed by [13] his study about the social media in rural context showed that the users tended to see social media as a place where things become visible to others. In other words, Facebook can serve the needs of its users. However, the three resource persons, although actively accessing their Facebook every day, did not feel that renewing the daily status was a necessity. All three agree that updating profile or status photos on the homepage is as needed and depends on the mood but not every day.

\subsection{The Relation between Language and Representation in Online Spaces}

Facebook is a social space that can be used for various social purposes. Interactions between users and their accounts make Facebook homepage as a virtual public space. This public space is constructed by the owner of the account according to their interests in order to connect with their Facebook friends. These interests can be in the form of information exchange or discussion, buying and selling activities, promotion, social interaction and self expression (subjectivity). The informants in this study did the same thing, using their account for the purposes mentioned above. However, they do it in different ways, for example in the language use. Based on the data collected through netnography, the author categorizes the use 
of language into two types, the local language (typical of Javanese language, LaranganBrebes), mixed language (from English and local languages), and Bahasa (its informal form). Apart from the language form, the topic of discussion will be part of the analysis. This aims to see and explain the relationship between language and the representation which becomes the corpus of this research. The first categorization is the use of the local language (Jawa Ngapak of Larangan-Brebes) as in the following post:

@Tina Takizawa "Q pan melu takon lurd.. bisane ari undar ta bs olih ijin ya ng lapangan...sedangkan kemah ta awit $q$ njagong $n g$ lapangan wis $5^{\text {th }}$ kiye ngonangi mung sepisan tok"

Translation - I want to ask all of you, why can the night market be permitted on the ground ... while for the campsite from the first time I lived here until my fifth year here, I only experienced it once

@ Chacha Mariska Heyhey "Bocah ora pd mikir... wong tua mumet golet duit malah pada senenge mbolos.dilawani kurang istirahat go nyekolahna anak tp laka trimakasihe"

Translation - the children are insensible ... while the parents are hardworking earning money, they like to skip school ... the parents don't even get enough rest to be able to send their children to school but the children are just so ungrateful

@ Triyono Rengganiest "Angger ora gelem.. kari ngomong... ari ora kiyeng kari ngomong... gampang oya"

Translation - if you don't want to, just let them know ... if you are reluctant, just let them know ... easy, right?

Based on the use of language and the subject matter, the informants interpreted Facebook home feed as an online social space to interact with the other Facebook users. The topic discussion posted by @Tina is considered as general topic, regarding permits from the local government. This topic can also invite other users to exchange opinions even though they are not from Javanese-speaking areas. However, the use of local languages makes the message only understood by the people who understand Javanese language. In other words the use of language limits the audience who can understand the language. Different from @Tina's post, the topics discussed in the @Triyono and @Chacha accounts are personal. The second topic of discussion expressed disappointment which means the owner of the account used their page as a private space. The topic of discussion also limits the audiences. Only the audience that is close or familiar with the owner of the account can respond or understand by commenting under the message. In this way@Triyono and @Chacha privatize public space into a private space. However, their way of privatizing public space on Facebook does not follow the privacy setting suggested by Facebook. As it stated by [10]Facebook gives users the freedom to limit their readers or audience when the information posted on their home page is personal. [14] Facebook users who do not utilize privacy setting are the same as they let anyone to see both their profiles and their posts.

In addition to privatize public spaces, the use of local language supported by personal topics represents the inability or confusion of Facebook users to distinguish between public space and private space. Facebook users will tend to post anything without considering the content of the message and setting their account into private. Thus, the local language, as the identity marker of the owner of the account, which used in online social spaces, represents two conflicting sides. Facebook's presence in a rural context represents modernity and it can also be implied that the modern lifestyle is accepted by people in the village. But this also sets 
another conflicting understanding where local Facebook users employ local language in communicating and interacting privately in a online public space. This also suggests that there is lack of understanding on the media literacy from the owner of the account.

The second categorization is mixed language. the mixed language that becomes the data in this study is the use of English words, specifically online languages or English slang mixed with Indonesian or local languages. The use of this mixed language is unique because it shows the user's creativity in mixing several elements of words from different languages yet it can form perfect meaning as in the following example:

@.Tri Widia Puspitaningrum "Panas2 COD SD Sembung 2 syumuk gaes, demi apa demi rupiah, eben kena go mangan enak maning, itu mulut yang suka nyinyir biar makin panas"

Translation - In the hot weather Cash On Delivery to SD Sembung 02,it's sweating, friends. What for, for the sake of rupiah (money) so we can eat well, those who nagged will only get hotter (angrier)

@ Triyono Rengganiest "Sekilas inpoh gaes, hp ku eroor, sementara komunikasi ga bisa lewat hp yah gaes"

Translation - Breaking news, friends. My phone is broken, currently any communication through phone will be unavailable, friends.

@Bunda Alya "Cepet pulang bapane ditunggu tandatangane sama raport mau dibagai hari kamis, pengen cepet libur ema 2 rempongnya juga pengen piknik kaya bapane"

Translation - Bapak (headmaster) quickly return home, (we are) waiting to ask for a signature, the student's report book will be given on Thursday, (we) want to have a vacation too, the other noisy ladies also want to have an outing like (you)

The post from@Tri and@Bunda combine three elements of language very well so the meaning of the phrase can be easily understood by the reader even when the reader does not specifically understand the Javanese terms. While the post from@Triyono, which combines two elements of language with short contents, allows readers to understand meaning without difficulty. The use of foreign language and loan words in the three posts above implies the frequency of the owner of the account in using social media. The more they are exposed to social media the more they get to understand foreign languages used in social media easily. As time goes by, foreign words are absorbed in and used in daily communication, they will consciously or unconsciously use these foreign words without trying to find the equivalent words from the local language or Bahasa. The use of mixed languages is not only found in online social spaces, the interviews show that the speakers often use Bahasa mixed with the foreign language when communicating directly. Some online terms that are often used verbally such as delivery (delivery), slow (selow), happy (hepi), notification (notification), confirm (confirmation), inbox (inbok). The informants easily inserted these foreign terms when they did not find the right equivalent words in Bahasa or the local language (Jawa Ngapak). It can also be said that this mixed language has been used so often that it no longer shows ineptness and feels natural instead.

The use of mixed language used by the informants represents the understanding of Facebook as a new cultural space where the use of online word terms are not only accepted but also consumed by the users. However, mixing online terms with Bahasa or local languages, either verbally or in writing, shows that the typical rural characters cannot escape even though new cultures have entered and are used well in everyday life. As a result of 
globalization, Facebook brings in new perspective of culture in the form of social media, and both people on the big city and the countryside can easily access it. Facebook with its extensive network makes local culture in this case the local language as a rural identity becomes known in the outside world. [15] found that social media for its extensive network is used as an identity contestation space by the users from Banyumas, through Facebook, Twitter and Weblog the users proudly use their local language (ngapak Banyumasan language) as a form of authenticity of their character. However the use of mixed language with the content of messages that are private represents the identity of the users which can be implied as people from the village with the low level of media literacy and can't distinguish well between private and public space in social media.

\section{CONCLUSION}

As a part of information and communication technology, Facebook has facilitated to reduce the impact of geographic isolation and increasing access to information and social connection for its users in rural context. The popularity of Facebook as a new instrument in communication and social interaction motivates the people in the village to widely use it to socialize and interact in a virtual world. However, their network of online connection which tends to be with people who live close by or from the same village makes the user see the Facebook online social space as a space to make everything visible. For the reason, their posts mostly tend to be about personal information using the local and mixed language as a tool to communicate in Facebook. The results of this research illustrate the connection between the use of local and mixed languages with the social media that represents the identity of the owner of the account, while the contents of message posted in the social space represent a lack of media literacy of the Facebook users to distinguish between the boundaries of public space and private space.

\section{REFERENCE}

[1] R. A. Nugroho, Ari Panggih; Elfitasari, Tita; Nugroho, "Pengaruh Komunitas Perikanan Budidaya di Media Sosial Facebook terhadap Kualitas Pembudidayaan Perikanan di Jawa Tengah," vol. 6, no. L, pp. 1-9, 2017.

[2] L. P. Supratman, "Penggunaan Media Sosial oleh Digital Native," J. ILMU Komun., vol. 15, no. 1, pp. 47-60, 2018.

[3] A. Zubair, "Fenomena Facebook: Keterlibatan Teknologi Komunikasi dalam Perkembangan Komunikasi Manusia,” J. ASPIKOM, vol. 1, no. 1, p. 60, 2017.

[4] J. van Dijck, "Facebook and the engineering of connectivity," Converg. Int. J. Res. into New Media Technol., vol. 19, no. 2, pp. 141-155, 2012.

[5] M. Burkell, Jacquelyn; Saginur, "'She's just a Small Town Girl, Living in an Online World': Differences and Similarities between Urban dan Rural Girls' Use of and Views about Online Social Networking," Univ. Ottawa Press, no. May 2016, 2013.

[6] J. Gilles and ; Tim Middleton, Studying Culture: A Practical Introduction. Massachusetts: Blackwell publisher, 1999.

[7] R. V. Kozinets, "The Field behind the Screen: Using Netnography for Marketing Research in Online Communities," J. Mark. Res., vol. 39, no. 1, pp. 61-72, 2003.

[8] H. Subiakto, "Internet untuk pedesaan dan pemanfaatannya bagi masyarakat (The usage of internet for the village and villagers)," Masyarakat, Kebud. dan Polit., vol. 26, no. 4, pp. 243-256, 2013. 
[9] D. R. Nugraha, P. Studi, I. Komunikasi, F. Komunikasi, D. A. N. Informatika, and U. M. Surakarta, "IMPLEMENTASI RUANG PUBLIK DALAM FANSPAGE," 2018.

[10] J. Burkell, A. Fortier, L. (Lola) Y. C. Wong, and J. L. Simpson, "Facebook: Public space, or private space?," Inf. Commun. Soc., vol. 17, no. 8, pp. 974-985, 2014.

[11] S. M. Ford, "Reconceptualizing the public/ private distinction in the age of information technology," Inf. Commun. Soc., vol. 14, no. 4, pp. 550-567, 2011.

[12] G. R. Adiarsi, Y. Stellarosa, and M. W. Silaban, "Literasi Media Internet di Kalangan Mahasiswa," Humaniora, vol. 6, no. 4, p. 470, 2017.

[13] T. McDonald, Social Media In Rural China. London: UCL Press, 2016.

[14] A. Nosko, E. Wood, and S. Molema, "All about me: Disclosure in online social networking profiles: The case of FACEBOOK," Comput. Human Behav., vol. 26, no. 3, pp. 406-418, 2010.

[15] E. Santoso, "Kontestasi Identitas di Media Sosial (Diskursus tentang Karakter dan Bahasa Banyumas di Weblog, Twitter dan Facebook)," Pros. Konf. Nas. Komun., vol. 01, no. 01, pp. 643-656, 2017. 